\title{
How to Determine the Influencing Cultural Factors on the Strategic Decision-Making Process in the Banking Sector?
}

\author{
Nizar Raissi ${ }^{1,2} \&$ Anas Hakeem ${ }^{2}$ \\ ${ }^{1}$ Laboratory ARBRE (Applied Research in Business Relationships \& Economics), University of Tunis, Tunisia \\ ${ }^{2}$ College of Islamic Economics and Finance, Umm Al Qura University, KSA \\ Correspondence: Nizar Raissi, College of Islamic Economics and Finance, Umm Al Qura University, KSA.
}

Received: January 30, 2017

Accepted: February 7, $2017 \quad$ Online Published: February 13, 2017

doi:10.5430/jms.v8n1p37

URL: http://dx.doi.org/10.5430/jms.v8n1p37

\begin{abstract}
This article studies the cross-cultural management research on the value and strategies adopted by bank managers while making banking decisions. Although, the study relied on testing causal relationships hypothesised in the research framework of multiple independent and intervening variables. To achieve this, a Structural Equation Modelling technique, was used to analyse the data collected from the survey of 200 respondents from 15 banking institutions. The findings show that the knowledge of bank managers is positively associated with the speed of the SDMP and participation. Likewise, the speed of decision making (SDM) is positively associated with the beliefs, attitudes and values of the top management team. Finally, the laws as a determinant of culture are positively associated to SDM and the degree of rationality.
\end{abstract}

Keywords: knowledge management, corporate culture, attitudes, strategic decision-making, analytical modeling

\section{Introduction}

Evidence from existing literature indicates that, for an organisation to become world-class in terms of policy formulation and implementation, its corporate culture has to be well integrated (Heracleous, L., \& Langham, B., 1996). Earlier studies on the impact of organisational culture in decision making are somewhat few and inadequate. Given the limited number of researches on the impact of corporate culture on decision making, there is a gap which needs to be addressed (Koskinen, J., et al., 2010). Generally, corporate decisions are often made in accordance with the culture of each organisation, which in turn helps to ensure the effective running of such organisations. This study will rely on different types of decision-making criteria on reliable corporate structure. Strategic decision-making in a firm also requires reliable communication channels and favourable working environments (Anderson, E.A. \& Adams D., 1997), for instance, new employees may undergo orientation programs to enable them understand the structure and traditions of the firm. For the most part, firms operate differently in their approach to decision making and communication. The reason for the difference in strategic decision-making processes and corporate culture is that, all firms have different goals and objectives, depending on their corporate culture (Powell, T.C., 1992). The creation of culture is an important thing that leaders do, managing it, is however the most important concern for managers. One of the most essential paradigms in recent studies is the culture-factor within organisations, and their effects on such organisation. The current research is a thematic study, to determine the potential influence of culture on strategic decision making processes, especially in the banking sector. The possible nexus between performance and decision making will also be investigated. The majority of studies on corporate culture mostly examine non-financial firms. A few of them have focused on developed countries. It should be acknowledged that, financial firms are influenced by different cultural factors. In this context, Islamic bank managers are for instance, influenced by the management practices in conventional banks. It is known that cultural change evolves over a relatively long period of time. Although these changes may precipitate modernisation in financial firms, Islamic values still display significant differences that can be traced back to their common root between these different systems. Consequently, the broader influence of corporate culture on investment decision making within Islamic and conventional banks is worth studying. This research adapted the wider organisational culture in business operations to create a better culture in Islamic banks (Abdul Rasid, S. Z., et al., 2013). Culture is defined by Schein, E.H., (1985), in terms of basic assumptions, shared beliefs or values. Also, Tylor, E. (1889) offered a broad definition, stating that culture is "that complex whole which includes knowledge, belief, art, morals, law, custom, and any other capabilities and habits acquired by man as a member of society". Additionally, according to Albert W. J., (1988), "The culture of a society 
is the whole complex of knowledge and beliefs and attitudes and practices which are embodied in the society and in its social, political and economic arrangements". Culture has equally been defined as "beliefs, assumptions, and values that members of a group share about rules of conduct, leadership styles, administrative procedures, ritual, and customs" (Schein, E. H., 1990, 1992, 1995; Mintzberg, H., 1990; Mehta, S. and Krishnan V.R., 2004). Also, the idea of culture has been construed as, "the shared philosophies, ideologies, values, assumptions, beliefs, expectations, attitudes and norms" (Kilmann, R., et al., 1985; Lund, D.B., 2003). The author Andrew B., $(1995,1998)$ cited by Sun, S, (2008) observes, that, "Organizational culture refers to the pattern of beliefs, values and learned ways of coping with experience that have developed during the course of an organization's history, and which tend to be manifested in its material arrangements and in the behaviours of its members". Furthermore, according to Dess, G.G., et al., (2007) organisational culture can be defined as a system of shared values, representing the company's most important elements, and beliefs. It also reflects the way in which things are done within the company that shape the employees, the organisational structure and control systems, in order to produce commonly accepted behavioural norms. Moreover, the way in which people behave is influenced by the ideologies, symbols and core values shared throughout the company (Hitt, M.E., et al., 2006). Also, Hofstede, G. (1991, 2001); Bogdan, I., Frăticiu, L., (2014); Obeidat, B., et al., (2012) indicated that organisational culture generally sums up the knowledge, beliefs, art, laws, moral norms or customs that serve to differentiate the groups from each other. A number of studies have argued, that, strong culture helps organisations to easily adjust to different changes, which may consequently enhance long-term performance (Salem, Z. O. \& Agil, S. O. S., 2012); (Ehtesham, M. et al. 2011). Thus, organisational culture helps to define how managers and employees think and make decisions, based on their knowledge or background experience, values and beliefs, and other considerations such as laws. Culture enhancement therefore helps to improve norms, objectives, and values of employees and their commitment to the organisation, and then enhances overall performance (Ahmed, M \& Shafiq, S., 2014). It is worth noting, that, the most significant factor influencing organisational performance is the organisational culture (Ahmed, M \& Shafiq, S., 2014). As a result, organisational culture should be consistent and adaptive. These features provide organisations with stable and homogeneous core values and behaviours. Employees should realise the variables of organisational culture, and take into account the awareness of goals and values of the organisation. Moreover, the implementation of cultural practices may decrease turnover rates and increase employee retention, career development, and job security. Additionally, employees have to learn about organisational culture such as beliefs, values, norms, knowledge, and laws (Ovidiu-Iliuta, D., 2014).

\section{Literature Review and Research Background}

\subsection{Organisational Culture Factors}

While cultural values are entrenched into the different models of cultural diversity, not all have an equal impact or importance in the study of SDM processes. Studies of national culture such as Parsons, T., \& Shils, E.A., (2001); Hills, M. D. (2002); Kluckhohn, F. R. \& Strodtbeck, F. L. (1961); McClelland, D. C. (1961), as well as models such as Hall, Edward T. (1976); Laurent, A. (1983, 1986); Hofstede, G., (1980) and Trompenaars, F., (1994), discuss critical cultural factors that affect businesses and economics such as knowledge (belief, attitudes and values), and laws that could influence managers' decision making processes. The primary finding of this study is that, an integrative model, which determines the influencing cultural factors of the strategic decision making process in banking should be developed. Moreover, the theoretical basis for this study is founded on the definitions below.

\subsubsection{Knowledge Factor}

Knowledge generally impacts on organisational decision making (Jarratt, D., \& Stiles, D., 2010). As demonstrated in this study, a sound management decision-making process and knowledge, if modelled in a proper way may help an organisation attain its goals (Vangelis, S., \& Marcello, M., 2010). Accordingly, John, P.L., (1995) indicates that, "I understand culture to be rooted in the shared knowledge and schemes created and used by a set of people for perceiving, interpreting, expressing, and responding to the social realities around them." Research usually classify knowledge management as either explicit knowledge or tacit knowledge types. For the most part, explicit knowledge tends to be viewed as contained in manuals and procedures. Tacit knowledge on the other hand is learned only by experience, and often communicated indirectly, through metaphor and analogy; Nonaka, I. \& Takeuchi, H. (1997) and Raissi, N., (2015). Recent research indicates that creating knowledge will become the key to sustaining a competitive advantage in the future. Because the competitive environment and customer preference changes constantly, knowledge perishes quickly.

\subsubsection{Belief, Attitudes and Values Factors}

Belief and values should manifest clearly in corporate decisions of banking managers, (Albdour, A.A., and Altarawneh, I.I., 2014). According to Eliot, T.S., (1888), it is necessary to emphasise that, the meaning of the word culture has the same connotation that we find in anthropological writings, which represents the mainstream. Eliot noted that, culture essentially suggests the way of life of a people, living together in one place and demonstrate this 
culture in their arts, social habits, customs and religion. Schein, E. H. $(1985,2004)$, asserts that, shared basic values (Schein prefers the term basic assumptions), operating at the deepest level of a group's culture are extremely difficult to change. Such values tend to be deeply entrenched and often not open to debate. Organisational culture has also been defined as, deeply rooted values and beliefs that are shared by people within an organisation (Sun, S., 2008). This preserves the social dynamics making up the organisation (values, beliefs, norms, assumptions), and helps build a strong culture (Ahmad, M.S., 2012). Beliefs and values, which are widely accepted as some of the strongest organisational cultural factors are related to the SDMP, which are a valuable source of a firm's competitive advantage (Ishak, et al., 2013). Thus, an organisation can achieve a greater level of success only when the shared values of employees matches up with organisational values. The organisation's internal environment is represented by its culture and is construed by the assumptions and beliefs of the managers and employees (Aycan, Z., et al., 1999).

\subsubsection{Laws Factor}

Law is identified as one of the important variables in the analysis of SDM processes which influences the politics of the process (Abu-Qaued, F.M. et al., 2014). Westbrook, J.K., (1993) affirms that, the culture of an organisation determines, the what, how, where, when, and whose suggestions are essential in facilitating the development of structures and performance of tasks. As such, it is the kind of direction given in terms of what should be done that brings about the intended result (Anderson, E.A. \& Adams D., 1997). Moreover, flexible systems in organisational culture tend to encourage innovation, communication, and effectiveness in the workplace, as compared to controlled processes that are efficient and in line with the culture and vision of an organisation (Robert A. \& Andrew S., 2007). Scholars observe that, a major feature of organisational culture is the connection between law and culture. There are generally three main approaches to explain this connection. The first approach is from the historical school, which arose in German jurisprudence, during the first half of the nineteenth century. It views law as a product of the national culture and as embedded in the daily practices of people. The second approach is, "the constitutive approach", developed in American jurisprudence in the 1980s. It views law as participating in the constitution of culture and invariably, in the constitution of people's minds and social relations. The third approach is found in twentieth century Anglo American jurisprudence, which view laws created and applied by courts as a distinct cultural system in their own right. Beyond these three approaches, nine additional approaches on the connection between law and culture have been identified such as "law and anthropology", "legal culture", "legal consciousness", "law and popular culture", "law and the production of cultural artifacts", "law and multiculturalism", "law and culture from the perspective of particular legal branches or doctrines", "law and culture in law and development", "law as an autopoietic system" (Mautner, M., 2011). Consequently, from the above approaches, there are strong connections between law and culture. Therefore, law is chosen as one of the dimensions of national culture.

\subsection{The Strategic Decision-Making Process (SDMP)}

Previous studies on the impact of organisational culture in the decision making process are few and largely inadequate. This is the primary motivation for this research. It is therefore interesting to understand the effects of culture on decision making, in line with the existing gaps (Koskinen, J., et al., 2010). Rajagopalan, N., et al., (1993), in a previous SDM study, noted four main features of the Strategic Decision-Making Process to include, speed of decision-making, the degree of rationality, political behaviours and the elements of involvement and participation. In the present research, the four strategic decision-making process factors will be employed to measure the link between SDMP and organisational culture factors.

\subsubsection{Speed of Decision-Making Factor}

The effect of the speed of SDMP on organisational culture has gained traction in recent studies. This is arguably because the business environment is more dynamic and the rate of change is faster. An instance of this is the rapid expansion of banking firms, especially, the international expansion of Islamic banking on the global stage. Judge, W.Q., \& Miller, A., (1991) identified important variables of the speed of the SDM process, such as, the ability to consider alternatives simultaneously, the size of the organisation, and the industry context.

\subsubsection{Degree of Rationality Factor}

The majority of studies previously regarded comprehensiveness and extensiveness as the indicators of rationality (Rajagopalan, N., et al., 1993). Recently, the study of the SDM process has received more attention, particularly in the aspect of using intuition to measure rationality. This can play an important role in making decisions (Miller, C.C., \& Ireland, R.D., 2005). Comprehensiveness is a measure of rationality and is defined as, 'the extent to which organizations attempt to be exhaustive or inclusive in making and integrating strategic decisions' (Fredrickson, J.W., \& Mitchell, T.R., 1984). Extensiveness is defined as 'the extent to which an upper-echelon executive group utilizes a substantial planning process to formulate long term goals and strategies for the firm' (Miller, D., et al., 1998). Intuition is defined as the ability to understand or know something immediately based on your feelings rather than 
facts (Online Cambridge English Dictionary, 2016).

\subsubsection{Political Behaviour Factor}

Political behaviour is defined as 'behavior by individuals, or, in collective terms, by sub-units within an organization, which make a claim against the resource-sharing system of the organization' (Pettigrew, A., 1973). Whether political behaviour is beneficial or harmful to organisations depend on the way it is used. Nonetheless, it may be necessary in some situations to drive and implement strategic changes (Mintzberg, H., 1990).

\subsubsection{Involvement and Participation Factor}

Participation in the strategic decision making process refers to the involvement of middle managers in the SDMP. This can have a higher strategic impact and considerably improve the implementation of the strategic decision choices. Managers at lower and middle levels are closer to business operations, are better informed about the market conditions, and are usually in a better position to generate and assess the alternatives, with directions from top management (Andersen, T.J., 2004), though the main essence of participation is to improve the quality of the decision rather than facilitating implementation (Wooldridge, B., \& Floyd, S.W., 1990).

\section{Research Questions}

This research addresses the effect of corporate cultural factors on the SDM process, using an integrative framework. The study concentrates on banking cultural factors that have a critical effect on the SDM process. Within this context, the following research questions would be considered:

1. What cultural factors are critical to the SDM process of banking?

2. How do these cultural factors affect bank managers in making strategic decisions?

3. What are the limitations of these cultural factors?

4. What are the managerial implications for both Islamic and Conventional banks?

For purposes of clarity, Islamic finance systems are referred to as Islamic banks or Islamic windows. Their regulations are largely derived from Sharia principles (Islamic law). The conventional finance system is identified as Conventional banks. The regulations of such banks are derived from the conventional finance regulations. Collectively, Islamic and Conventional banks form the broader banking system. The generic term 'banking', is used to refer to the two groups.

\section{Hypotheses}

There are three groups of hypotheses that demonstrate the relationships between the three cultural factors and the SDM process. There is a link between the knowledge of bank managers (decision makers), and the speed of decision making, degree of rationality, and participation and involvement of the SDM process. The knowledge of top management teams impact on organisational decision making (Jarratt, D., \& Stiles, D., 2010). As demonstrated in this study, a sound management decision-making process, and the knowledge, if modelled in a proper way could help an organisation attain its goals (Vangelis S., \& Marcello M., 2010). This indicates that, knowledge and the degree of rationality are always entwined, to help organisations achieve their goals. Recent researches indicate that, knowledge creation will become the key to sustaining a competitive advantage in the future. Because competitive environments and customer preferences changes constantly, knowledge also diminishes, quite rapidly. In other words, knowledge creation and speed of decision making are linked to each other, to help organisations achieve a competitive advantage. Moreover, it limits the participation of middle and lower level managers, thereby reducing the chances of a competitive advantage and knowledge creation. However, participation/involvement have a positive relationship with the knowledge of top management (Koskinen, J., et al, (2010); Rajagopalan, N., at al., (1993); Parsons, T., \& Shils, E.A., (2001); Hills, M. D. (2002); Kluckhohn, F. R. \& Strodtbeck, F. L. (1961); John P.L., (1995); Nonaka, I. \& Takeuchi, H., (1997); Raissi, N., (2015); Wooldridge, B., \& Floyd, S.W., (1990)). This leads to the following hypotheses:

Hypothesis 1a: The knowledge of bank managers will positively affects the speed of the SDM process.

Hypothesis $1 b$ : The knowledge of bank managers will negatively affects the degree of rationality.

Hypothesis $1 c$ : The knowledge of bank managers will positively affects political behaviour.

Hypothesis 1d: The knowledge of bank managers will negatively affects participation.

The beliefs, attitudes, and values underlying the decisions of top management teams, have a relationship with all the SDM processes. Important decisions, such as, strategic decisions are made or at least monitored, as well as influenced, by beliefs, attitudes and values of the top management team. However, if these decisions get the attention of individuals at the highest level, they can be decided quickly. This is a reflection of being less dependent on formal 
procedures. It is important to maintain harmony, and avoid conflict, because these are viewed as threats to the collective interest. As a result of these beliefs, attitudes, and values, managers will generally not question the rationale behind the chief executive's decision, and will accept and execute them in good faith. Thus, strategic decisions are mostly limited to those at the top, thereby reducing the degree of rationality (Ahmad, M.S., (2012); Ishak, M.S., et al., (2013); Judge, W.Q., \& Miller, A., (1991); Aycan, Z., et al., (1999)). This leads to the following hypotheses:

Hypothesis 2a: Beliefs, attitudes and values of the top management team will positively affect the speed of decision making. rationality.

Hypothesis $2 b$ : Beliefs, attitudes and values of the top management team will negatively affect the degree of

Hypothesis 2c: Beliefs, attitudes and values of the top management team will negatively affect participation. behaviour.

Hypothesis $2 d$ : Beliefs, attitudes and values of the top management team will negatively affect political

Laws affect every facet of the SDM processes (Abu-Qaued, F.M. et al., 2014). The collectivist nature of Arabian cultures, for instance, leads to a longer process of decision making, as time is spent on reaching a group consensus. Since there are strong connections between law and culture, whereby law is viewed as participating in the constitution of culture and consequently, in the constitution of people's minds and social relations (American jurisprudence in the 1980s). Big decisions are made or at least monitored, as well as influenced, by laws. Managers often recognise the importance of laws while conducting business. Building and maintaining laws can be a high priority in making managerial decisions. Flexible systems in strategic decisions should therefore tend to encourage innovation, communication, and effectiveness in the workplace with the highest participation. They can be decided quickly when strategic decisions are regarded as important (Mautner, M., (2011); Miller, C.C., \& Ireland, R.D. (2005); Westbrook, J.K., (1993); Anderson, E.A. \& Adams D., (1997); Robert A. \& Andrew S., (2007); Mintzberg, H., (1990)). This leads to the following hypotheses:

Hypothesis $3 a$ : Laws will positively affect the speed of decision making.

Hypothesis $3 b$ : Laws will positively affect the degree of rationality.

Hypothesis 3c: Laws will negatively affect participation.

Hypothesis $3 d$ : Laws will positively affect political behaviour.

Figure 1 summarises the hypotheses within the conceptual framework of this study. A plus sign $(+)$ indicates a positive influence and a minus sign (-) indicates a negative relationship between the two variables.

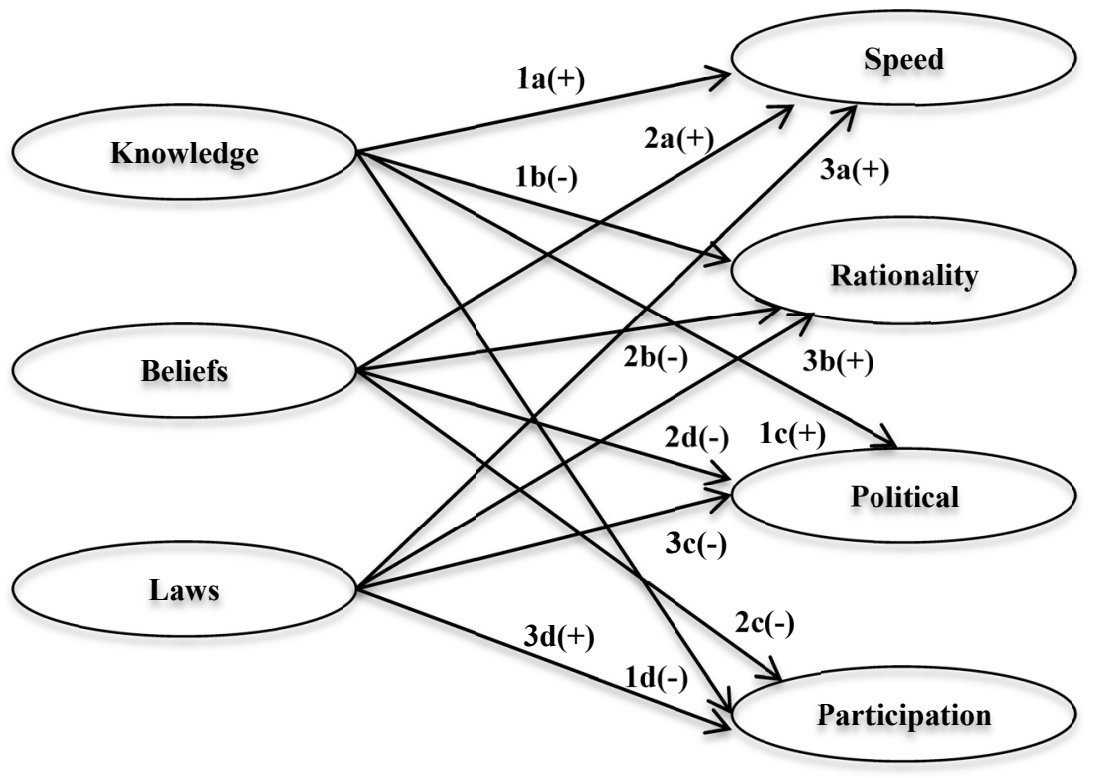

Figure 1. Conceptual framework 


\section{Methodology}

\subsection{Sampling and Data Collection}

Cross-cultural management research on the value, similarities and differences between Islamic and conventional banks provide evidence that, economic development leads to a convergence of value orientation among societies. Although both Islamic and conventional bank managers are sampled in this study, they are considered as representatives of the banking systems in strategic decision making behaviour. An exploratory research technique is adopted for the purpose of this study. The exploratory technique is mainly related to the exploration theory of development that most researches use. This technique is a quantitative approach that focuses on organisational culture. The relevant questionnaire on organisational culture is aimed at identifying the cultural particularities present within Islamic banks, as well as in conventional banks with an Islamic window, especially on the effects of culture on SDMP. These questionnaires will be directed at the top, middle and lower level management in the banking sector, particularly the most successful banks in Saudi Arabia. The data was analysed using SPSS (a statistical software package) and SmartPLS (Statistical software for Structural Equation Modelling). The methodology of this research aims to quantitatively measure the impact of organisational culture on strategic decision making process in banking. In total, 1000 participants (managers) were randomly selected from the total of 15 banking institutions in Saudi Arabia. A structured questionnaire was sent and returned via email with electronic link, and a covering letter, stating the purpose. Confidentiality was ensured with the anonymously returned questionnaire. A final 200 valid questionnaires were returned (i.e., $20 \%$ response rate) for this study.

\subsection{Instrument Design}

A five-point Likert scale, ranging from strongly agree (5) to strongly disagree (1) was used in all questions. The questionnaire was administered and 10 managers from different banks reviewed the questionnaire to ensure they were clearly formulated. No modification was required after their feedback. The scales used to measure the three corporate cultural factors of SDM were obtained from previous cultural surveys. Items for 'laws' were derived from (American jurisprudence in the 1980s, German jurisprudence, Anglo American jurisprudence). Items for 'Beliefs,' 'Attitudes and Values' as well as 'Knowledge' were obtained from (Eliot, T.S., (1888); Schein, E. H., (1985, 2004); Sun, S., (2008); Albert, W.J., (1988); Mintzberg, H., (1990); Mehta, S. and Krishnan V.R., (2004); Kilmann, R., et. al (1985); Lund, D.B., (2003); Andrew B., (1995, 1998); Dess, G.G., et al. (2007); Hitt, M.E., et al. (2006); Hofstede, G., $(1991,2001))$. In the SDM process, items for 'speed' were obtained from Miller, D., et al., (1998) and Frishammar, J., (2003). Items for 'rationality' were obtained from Eisenhardt, K. M., and Zbaracki. M. J., (1992) and Said, E., (2006). Items for 'political behaviour' were derived from Eisenhardt, K., \& Bourgeois, L.J., (1988). Items for 'participation' were obtained from Pettigrew, A., (1973), and Eisenhardt, K., \& Bourgeois, L. J. (1988, 1989).

\subsection{Analysis Procedure}

This study focuses on the establishment of bank's (Islamic and conventional banks) SDM processes. It relies on testing causal relationships hypothesised in the research framework (Figure 1) of multiple independent and intervening variables. To achieve this, a structural equation modelling technique was used to analyse the data collected from the survey. The data analysis was conducted using SPSS (Statistical Package for the Social Sciences) and SmartPLS (Partial Least Squares Path Modelling) software package. A recommended two step model-building approach was adopted (Anderson, J.C., \& Gerbing, D.W., 1988). The SEM model was separated into a measurement model and a structural model. The measurement model consisted of relationships between the latent variables and their indicators, while the structural model showed the causal relationships among the latent variables (Williams, L.J., et al., 2003).

\section{Results}

\subsection{Descriptive Statistics}

Our sample integrates two respondent categories, one for Islamic banks, with $42 \%$, and the other for $58 \%$. A total of 13 banks and 2 financial establishments in Saudi Arabia, are engaged with in this study.

Table 1. Nature of banks respondents

\begin{tabular}{llcccc}
\hline & & Frequency & Percent & Valid Percent & Cumulative Percent \\
\hline Valid & Conventional Banks & 116 & 58.0 & 58.0 & 58.0 \\
& Islamic Banks & 84 & 42.0 & 42.0 & 100.0 \\
& Total & 200 & 100.0 & 100.0 & \\
\hline
\end{tabular}


The nature of our sample is defined by $66.5 \%$ managers, and about $69 \%$ hold undergraduate degrees for different category (managers, auditor, customer service manager, assistant manager, general manager...). The Respondents are divided to $76.5 \%$ males with $23.5 \%$ females.

\subsection{Validity of Measurement Scale}

We began our analysis with three variables which represent the culture determinants (Knowledge, Laws and beliefs) as independent variables, and with four variables which represent the SDMP dimensions as dependent variables (Speed, rationality, political and participation). These measures established to test the correspondence between constructs and their items and within the item's coherence. The operations on empirical measures in the context of the statistical analysis of results should be in consonance with the relations that is legitimate to establish between the concepts studied. We chose in this approach to validate our measurement scale (items). For dependent and independent variables, three statistical measures were adopted (the reliability test by Cronbach Alpha, the validity with normality test by Skewness and Kurtosis coefficients, and Total Explained Variance). Although, the validation of items was defined by Principal Component Analysis (PCA). Table 2 below shows the main results obtained after reliability and validity tests.

Table 2. Exploratory factor analysis of measurement scales

\begin{tabular}{|c|c|c|c|c|c|c|c|}
\hline \multirow{2}{*}{ Variables } & \multirow[b]{2}{*}{ Code } & \multirow{2}{*}{$\begin{array}{l}\mathrm{N} \text { of } \\
\text { Items }\end{array}$} & \multirow{2}{*}{$\begin{array}{c}\text { Cronbach's } \\
\text { Alpha }\end{array}$} & \multirow{2}{*}{$\begin{array}{l}\text { Normality } \\
\text { test } \\
\text { (Skewness } \\
\text { and } \\
\text { Kurtosis) }\end{array}$} & \multicolumn{2}{|c|}{ KMO and Bartlett's Test } & \multirow{2}{*}{$\begin{array}{l}\text { Total Variance } \\
\text { Explained } \\
\text { (Cumulative \%) }\end{array}$} \\
\hline & & & & & $\begin{array}{c}\text { Kaiser-Meyer-Olkin } \\
\text { Measure }\end{array}$ & $\begin{array}{c}\text { Bartlett's } \\
\text { Test } \\
\text { (Sig.) }\end{array}$ & \\
\hline Knowledge & KNOW & 20 & 0.93 & $\begin{array}{l}20 \text { items } \\
\text { retained }\end{array}$ & 0.89 & 0.00 & 56.34 \\
\hline Laws & LAWS & 8 & 0.82 & $\begin{array}{l}8 \text { items } \\
\text { retained }\end{array}$ & 0.73 & 0.00 & 62.36 \\
\hline Beliefs & BEL & 11 & 0.91 & $\begin{array}{l}11 \text { items } \\
\text { retained }\end{array}$ & 0.84 & 0.00 & 66.16 \\
\hline Speed & SDM & 2 & 0.90 & $\begin{array}{l}2 \text { items } \\
\text { retained }\end{array}$ & 0.50 & 0.00 & 91.34 \\
\hline Rationality & DRA & 6 & 0.84 & $\begin{array}{l}6 \text { items } \\
\text { retained }\end{array}$ & 0.78 & 0.00 & 75.25 \\
\hline Political & PBEH & 4 & 0.80 & $\begin{array}{l}4 \text { items } \\
\text { retained }\end{array}$ & 0.73 & 0.00 & 79.93 \\
\hline Participation & EIAP & 3 & 0.86 & $\begin{array}{l}3 \text { items } \\
\text { retained }\end{array}$ & 0.72 & 0.00 & 91.33 \\
\hline
\end{tabular}

The results as presented in Table 2 show that all the dependent and independent variables were retained. To estimate the reliability, the Cronbach's Alpha was calculated for items and the values exceeding $70 \%$ (between $81 \%$ and $94 \%$ ). This level is accepted for measurement scales, and the result proves that there is a high degree coherence between the items of each construct, although the 7 variables tested are internally consistent and have acceptable reliability values. Once, the reliability of items was approved, the validity of items was calculated with normality test (Skewness and Kurtosis coefficients). The results show that all items are accepted and all of them were between -3 and 3. The final step for exploratory analysis is to find the loading of each item and factors with Total Variance Explained (VE). The results of Kaiser-Meyer-Olkin (KMO) test and Bartlett's test of sphericity are statistical significant for all items, and the variance analysis shows that the items retained and factors exceed $60 \%$ for all variables.

\subsection{Confirmatory Factor Analysis}

To test the strength and direction of correlation between the various criteria of the conceptual model, we opt for a quantitative methodology, by way of structural equation modelling. SEMs are recent developments and the most 
significant in the studies and in marketing research; Evrard, Y., et al., (2009) and Vilares, M.J., et al., (2009). The SEM can be seen as a combination of both approaches, previously dealt with separately:

- Analysis of latent variables: we consider that the observed variables directly reflect, or affect other variables not directly observable.

- Structural models: designed to represent and to estimate causal relationships between variables; representations commonly used in the form of a set of linear equations. These are simultaneous equations or network analysis or path modelling.

Moreover, the full path model tested in this article combined two sub-models: the structural model, referred to as inner model, and the measurement model, referred to as outer model. The inner model which describes only the relationships between latent variables and the outer model is the part that concerns the relationship between each construct and its indicators (Evrard, Y., et al., 2009). We begin with the presentation of two components of causal models: confirmatory factor analysis (measurement model) and the simultaneous equations (structural model), then we discuss their integration into the structural equations with latent variables and measurement error. In this section, we use SmartPLS software of structural equation modelling analysis. For each construct, the measures were purified using item-to-item total correlations, single measurement models, and CFA (Confirmatory Factor Analysis). The analysis of our model begins by testing indicators with their constructs, and to assess measurements model by calculating the Composite reliability, Indicator reliability and Average variance extracted (AVE). The data analysis results of 7 constructs which represent the research model (endogenous and exogenous variables) are summarised in Table 3 below:

Table 3 . The reliability and validity of constructs

\begin{tabular}{lccccc}
\hline \multicolumn{1}{c}{ Constructs } & Code & N of Items & $\begin{array}{c}\text { Cronbach's } \\
\text { Alpha }\end{array}$ & $\begin{array}{c}\text { Jöreskog's } \\
\text { Rhos }\end{array}$ & $\begin{array}{c}\text { Average Variance } \\
\text { Extracted (AVE) }\end{array}$ \\
\hline Knowledge & KNOW & 8 & 0.89 & 0.90 & 0.53 \\
Laws & LAWS & 3 & 0.82 & 0.82 & 0.61 \\
Beliefs & BEL & 6 & 0.86 & 0.89 & 0.58 \\
Speed & SDM & 2 & 0.90 & 0.95 & 0.91 \\
Rationality & DRA & 6 & 0.85 & 0.88 & 0.56 \\
Political & PBEH & 3 & 0.78 & 0.87 & 0.70 \\
Participation & EIAP & 3 & 0.86 & 0.91 & 0.78 \\
\hline
\end{tabular}

Then, the purification of all items given in final step 31 items represents 7 latent variables. The items are distributed as follows: 8 items of knowledge, 3 items of laws, and 6 items of beliefs defined all the determinants of culture. Moreover, 2 items of speed, 6 items of rationality, 3 items of both political and participation defined all the determinants of strategic decision making process (SDMP). Also, Assessing Reflective Measurement Models should begin by taking reliability and validity into account. The first criteria checked is internal consistency reliability with Cronbach's alpha which used as an estimate of the reliability of a psychometric test (Cronbach, L.J., 1951). In our case, all Cronbach's alpha (Absolute standardised outer (component) loadings) are more than $70 \%$, these results show that there is a high inter-correlation between measurement scales of each constructs. Whereas a value that exceeds 0.6 indicates a strong reliability. The second criterion checked is Jöreskog's Rhos, which helps to measure the internal consistency and must not be lower than $60 \%$. The Table 3 shows that Jöreskog's Rhos values are more than $80 \%$, which greatly exceeds the threshold of 0.6 . These results reflect that the internal consistency of all items is high and there are a very strong correlation between items and their constructs. The high values of this criterion approved items as scales. When taken as a group, they are fairly well significant in the model. Thus, the assessment of validity needs to examine the convergent validity and the discriminant validity. Fornell, C., \& Larcker, D.F., (1981) propose using the Average Variance Extracted as a criterion of convergent validity. Then, the third main criterion which should be calculated to validate our measurement scales is the AVE. This criterion should be higher than 50\%. In our case, all AVE values are more than 53.5\%. That the AVE values are all more than 0.5 indicate sufficient convergent validity. This means that a given factor (latent variable) is able to explain more than half of the variance of its indicators on average (Götz, O., et al., 2009). Once, the AVE is calculated, the discriminant validity should be examined with two measures, the first is The Fornell-Larcker criterion (Table 4), and the second is crossloadings (Table 5). 
Table 4. Fornell-Larcker Criterion

\begin{tabular}{lccccccc}
\hline & Bel & DRA & EIAP & Know & Laws & PBEH & SDM \\
\hline Bel & 0.76 & & & & & & \\
DRA & 0.20 & 0.75 & & & & & \\
EIAP & 0.06 & 0.64 & 0.88 & & & & \\
Know & 0.75 & 0.21 & 0.15 & 0.73 & & & \\
Laws & 0.47 & -0.04 & -0.12 & 0.54 & 0.78 & & \\
PBEH & 0.07 & 0.74 & 0.57 & 0.03 & -0.18 & 0.83 & 0.95 \\
SDM & 0.22 & 0.56 & 0.53 & 0.23 & -0.16 & 0.51 & \\
\hline
\end{tabular}

The authors Fornell, C., \& Larcker, D.F., (1981) postulated that, each latent variable should have a correlation with its indicators more than other latent variables. In order to ensure discriminant validity, the AVE of each construct should be greater than the latent variable's highest squared correlation with any other latent variable. In our case, the AVE values of all latent variables are as follows: the value of Beliefs variable is 0.767 , Rationality is 0.753 , Participation is 0.885 , Knowledge is 0.731 , Law is 0.784 , Political is 0.837 , while that of Speed is 0.956 . All the values show that the self AVE of each latent variable is more than the other variables. Generally, the loading of each indicator is expected to be greater than all of its cross-loadings (Chin, W.W., 1998; Götz, O., et al., 2009). In our case, the Table 5 shows the cross loadings of all latent variables with its indicators.

Table 5. Cross loadings

\begin{tabular}{|c|c|c|c|c|c|c|c|}
\hline & Bel & DRA & EIAP & Know & Laws & PBEH & SDM \\
\hline Bel1 & 0.81 & 0.10 & -0.01 & 0.56 & 0.44 & 0.01 & 0.17 \\
\hline Bel10 & 0.68 & 0.07 & 0.02 & 0.57 & 0.52 & 0.03 & 0.10 \\
\hline Bel12 & 0.83 & 0.21 & 0.15 & 0.75 & 0.36 & 0.07 & 0.23 \\
\hline Bel4 & 0.68 & 0.05 & 0.05 & 0.67 & 0.54 & -0.06 & 0.03 \\
\hline Bel7 & 0.72 & 0.15 & 0.07 & 0.45 & 0.24 & 0.11 & 0.16 \\
\hline Bel8 & 0.83 & 0.16 & -0.03 & 0.52 & 0.35 & 0.07 & 0.19 \\
\hline DRA1 & 0.14 & 0.75 & 0.48 & 0.18 & -0.00 & 0.69 & 0.50 \\
\hline DRA2 & 0.11 & 0.79 & 0.60 & 0.11 & -0.11 & 0.75 & 0.47 \\
\hline DRA3 & 0.07 & 0.65 & 0.33 & 0.01 & -0.05 & 0.71 & 0.39 \\
\hline DRA4 & 0.32 & 0.78 & 0.42 & 0.24 & 0.05 & 0.44 & 0.42 \\
\hline DRA5 & 0.11 & 0.71 & 0.48 & 0.14 & -0.07 & 0.45 & 0.43 \\
\hline DRA6 & 0.05 & 0.79 & 0.55 & 0.18 & -0.05 & 0.46 & 0.34 \\
\hline EIAP1 & 0.06 & 0.59 & 0.91 & 0.17 & -0.13 & 0.54 & 0.42 \\
\hline EIAP2 & 0.09 & 0.54 & 0.84 & 0.11 & -0.04 & 0.45 & 0.56 \\
\hline EIAP3 & 0.03 & 0.56 & 0.90 & 0.10 & -0.13 & 0.50 & 0.51 \\
\hline Know 1 & 0.56 & 0.21 & 0.15 & 0.85 & 0.45 & 0.04 & 0.16 \\
\hline Know 2 & 0.51 & 0.14 & 0.01 & 0.70 & 0.37 & -0.10 & 0.11 \\
\hline Know 20 & 0.72 & 0.22 & 0.09 & 0.74 & 0.44 & 0.06 & 0.19 \\
\hline Know 3 & 0.57 & 0.20 & 0.18 & 0.86 & 0.46 & 0.05 & 0.21 \\
\hline Know 4 & 0.52 & -0.01 & 0.01 & 0.62 & 0.60 & -0.05 & 0.01 \\
\hline Know 5 & 0.51 & 0.01 & -0.02 & 0.64 & 0.47 & -0.03 & 0.07 \\
\hline Know 7 & 0.45 & 0.03 & -0.00 & 0.63 & 0.57 & -0.00 & 0.01 \\
\hline Know 8 & 0.56 & 0.08 & 0.13 & 0.72 & 0.34 & 0.02 & 0.21 \\
\hline Laws 2 & 0.38 & 0.00 & 0.07 & 0.43 & 0.64 & 0.06 & -0.03 \\
\hline Laws 3 & 0.34 & -0.06 & -0.07 & 0.35 & 0.71 & -0.04 & -0.08 \\
\hline PBEH1 & 0.04 & 0.54 & 0.51 & 0.01 & -0.20 & 0.85 & 0.49 \\
\hline РBEH3 & 0.06 & 0.69 & 0.47 & 0.01 & -0.12 & 0.76 & 0.31 \\
\hline PBEH4 & 0.09 & 0.65 & 0.44 & 0.06 & -0.11 & 0.88 & 0.45 \\
\hline SDM2 & 0.19 & 0.56 & 0.56 & 0.21 & -0.16 & 0.50 & 0.95 \\
\hline SDM3 & 0.24 & 0.51 & 0.45 & 0.22 & -0.15 & 0.47 & 0.95 \\
\hline Laws 1 & 0.47 & -0.02 & -0.09 & 0.56 & 0.95 & -0.17 & -0.16 \\
\hline
\end{tabular}


The analysis of our criterion results show that, the reliability and the validity of reflective measurement of latent variables are confirmed for all indicators. In second step, the assessing of formative measurement model is needed to complete the confirmatory factor analysis part. According to Diamantopoulos, A., \& Winklhofer, H., (2001); Cassel, C.M., et al., (2000); Grewal, R., et al., (2004); Davison, A.C., \& Hinkley, D.V., (2003); Chin, W.W., (1998) and Tenenhaus, M., et al., (2005), there are four criterion which should be tested, the Nomological validity, the External validity, the Significance of weights and the Multicollinearity. The discriminant validity however begins by calculating the criterion of Heterotrait-Monotrait Ratio as presented in Table 6 below, with bootstrapping routine in SmartPLS.

Table 6. The Heterotrait-Monotrait Ratio (HTMT)

\begin{tabular}{lccccc}
\hline & $\begin{array}{c}\text { Original } \\
\text { Sample }(\mathrm{O})\end{array}$ & $\begin{array}{c}\text { Sample Mean } \\
(\mathrm{M})\end{array}$ & $\begin{array}{c}\text { Standard } \\
\text { Deviation } \\
(\text { STDEV })\end{array}$ & $\begin{array}{c}\text { T Statistics } \\
(\mid \mathrm{O} / \text { STDEV } \mid)\end{array}$ & P Values \\
\hline DRA -> Bel & 0.20 & 0.23 & 0.04 & 4.66 & 0.00 \\
EIAP -> Bel & 0.09 & 0.13 & 0.03 & 2.75 & 0.00 \\
EIAP -> DRA & 0.72 & 0.72 & 0.04 & 16.82 & 0.00 \\
Know -> Bel & 0.86 & 0.86 & 0.03 & 26.00 & 0.00 \\
Know -> DRA & 0.19 & 0.22 & 0.03 & 5.81 & 0.00 \\
Know -> EIAP & 0.12 & 0.15 & 0.04 & 2.95 & 0.00 \\
Laws -> Bel & 0.61 & 0.61 & 0.05 & 11.02 & 0.00 \\
Laws - DRA & 0.12 & 0.15 & 0.03 & 4.00 & 0.00 \\
Laws -> EIAP & 0.10 & 0.13 & 0.03 & 2.84 & 0.00 \\
Laws - Know & 0.71 & 0.71 & 0.05 & 13.48 & 0.00 \\
PBEH -> Bel & 0.11 & 0.14 & 0.04 & 2.71 & 0.00 \\
PBEH -> DRA & 0.95 & 0.95 & 0.03 & 28.37 & 0.00 \\
PBEH -> EIAP & 0.68 & 0.67 & 0.05 & 11.47 & 0.00 \\
PBEH -> Know & 0.09 & 0.14 & 0.03 & 3.22 & 0.00 \\
PBEH -> Laws & 0.13 & 0.16 & 0.03 & 4.04 & 0.00 \\
SDM -> Bel & 0.22 & 0.23 & 0.05 & 3.76 & 0.00 \\
SDM -> DRA & 0.64 & 0.64 & 0.06 & 10.36 & 0.00 \\
SDM - EIAP & 0.62 & 0.62 & 0.04 & 13.46 & 0.00 \\
SDM -> Know & 0.19 & 0.21 & 0.05 & 3.69 & 0.00 \\
SDM -> Laws & 0.12 & 0.14 & 0.05 & 2.17 & 0.03 \\
SDM -> PBEH & 0.59 & 0.59 & 0.07 & 8.48 & 0.00 \\
\hline
\end{tabular}

As Henseler, J., et al., (2016) demonstrated in their research, when using HTMT criterion to assess discriminant validity, if the HTMT value is less than 0.90 , the discriminant validity has been established between two reflective constructs. In our case, the p-values of all constructs tested by bootstrapping Heterotrait-Monotrait Ratio presents a statistical significance and the formative constructs are valid. The multicollinearity test of Manifest variables in a formative block is calculated by the variance inflation factor (VIF). In general, the value of VIF greater than 10 indicates the presence of harmful collinearity. Conversely, any VIF significantly greater than 1 indicates multicollinearity.

Table 7. The inner VIF values

\begin{tabular}{|c|c|c|c|c|c|c|c|}
\hline & $\mathrm{Bel}$ & DRA & EIAP & Know & Laws & PBEH & SDM \\
\hline $\mathrm{Bel}$ & & 2.33 & 2.33 & & & 2.33 & 2.33 \\
\hline \multicolumn{8}{|l|}{ DRA } \\
\hline \multicolumn{8}{|l|}{ EIAP } \\
\hline Know & & 2.58 & 2.58 & & & 2.58 & 2.58 \\
\hline Laws & & 1.45 & 1.45 & & & 1.45 & 1.45 \\
\hline \multicolumn{8}{|l|}{ PBEH } \\
\hline SDM & & & & & & & \\
\hline
\end{tabular}


In our case, all of VIF values is greater than 1 and less than 10 as presented in Table 7. The multicollinearity of all formative indicators was approved and there are not highly collinear formative indicators. Then, all of formative indicators in model are statistical significant. Chin, W.W., (1998) describes the $\mathrm{R}^{2}$ as substantial if the value is 0.67 , moderate, if the value is 0.33 , and weak, if the value is 0.19 . Two cases should be first identified when certain Inner path model structures explain endogenous latent variables by only a few exogenous variables, moderate $\mathrm{R}^{2}$ may be accepted. Otherwise, the $\mathrm{R}^{2}$ should be accepted for substantial value.

Table 8. The R Square of endogenous latent variables

\begin{tabular}{lccccc}
\hline & $\begin{array}{c}\text { Original } \\
\text { Sample }(\mathrm{O})\end{array}$ & $\begin{array}{c}\text { Sample Mean } \\
(\mathrm{M})\end{array}$ & $\begin{array}{c}\text { Standard } \\
\text { Deviation } \\
\text { (STDEV })\end{array}$ & $\begin{array}{c}\text { T Statistics } \\
(\mid \mathrm{O} / \text { STDEV } \mid)\end{array}$ & P Values \\
\hline DRA & 0.09 & 0.12 & 0.03 & 2.62 & 0.00 \\
EIAP & 0.09 & 0.10 & 0.04 & 2.16 & 0.03 \\
PBEH & 0.07 & 0.09 & 0.04 & 1.66 & 0.09 \\
SDM & 0.19 & 0.18 & 0.05 & 3.38 & 0.00 \\
\hline
\end{tabular}

In our case, the p-value of Rationality (DRA) variable, Participation (EIAP) variable and Speed (SDM) variable which represents the endogenous latent variables of structural model are statistical significant (Table 8). Tenenhaus, M., et al., (2005), assured that the estimated value for path coefficients in the structural model should be assessed in terms of sign, magnitude, and significance (using bootstrapping routine). And the path coefficients can be used in examining the possible causal relationships between endogenous and exogenous variables in the structural equation modelling approach.

Table 9. The estimates of path coefficients

\begin{tabular}{lccccc}
\hline & $\begin{array}{c}\text { Original } \\
\text { Sample }(\mathrm{O})\end{array}$ & $\begin{array}{c}\text { Sample Mean } \\
(\mathrm{M})\end{array}$ & $\begin{array}{c}\text { Standard } \\
\text { Deviation } \\
(\text { STDEV })\end{array}$ & $\begin{array}{c}\text { T Statistics } \\
(\mid \mathrm{O} / \text { STDEV })\end{array}$ & P Values \\
\hline Bel -> DRA & 0.12 & 0.13 & 0.13 & 0.93 & 0.34 \\
Bel -> EIAP & -0.06 & -0.05 & 0.12 & 0.54 & 0.58 \\
Bel -> PBEH & 0.16 & 0.14 & 0.12 & 1.32 & 0.18 \\
Bel -> SDM & 0.19 & 0.19 & 0.10 & 1.84 & 0.06 \\
Know -> DRA & 0.26 & 0.24 & 0.16 & 1.58 & 0.11 \\
Know -> EIAP & 0.37 & 0.31 & 0.14 & 2.51 & $0.01^{*}$ \\
Know -> PBEH & 0.08 & 0.06 & 0.14 & 0.56 & 0.57 \\
Know -> SDM & 0.32 & 0.27 & 0.12 & 2.54 & $0.01^{*}$ \\
Laws -> DRA & -0.25 & -0.24 & 0.11 & 2.19 & $0.02^{*}$ \\
Laws -> EIAP & -0.29 & -0.23 & 0.14 & 2.01 & $0.04^{*}$ \\
Laws -> PBEH & -0.31 & -0.25 & 0.17 & 1.74 & 0.08 \\
Laws -> SDM & -0.43 & -0.35 & 0.15 & 2.93 & $0.00^{*}$ \\
\hline
\end{tabular}

$* \mathrm{p}<.05$

According to Table 9, there are 5 significant relationships. The first and the second relationship is between Knowledge, Participation and Speed; the third, fourth and fifth relationship is between Laws, Rationality, Participation and Speed. The other p-values are more than 5\% and they are of no statistical significance. The causality is limited to Knowledge and Laws as exogenous variables within Rationality, Speed and Participation as endogenous variables. The structural model with estimated parameters explain more of these causal relationships between dependent and independent variables as presented in Figure 2 below. 


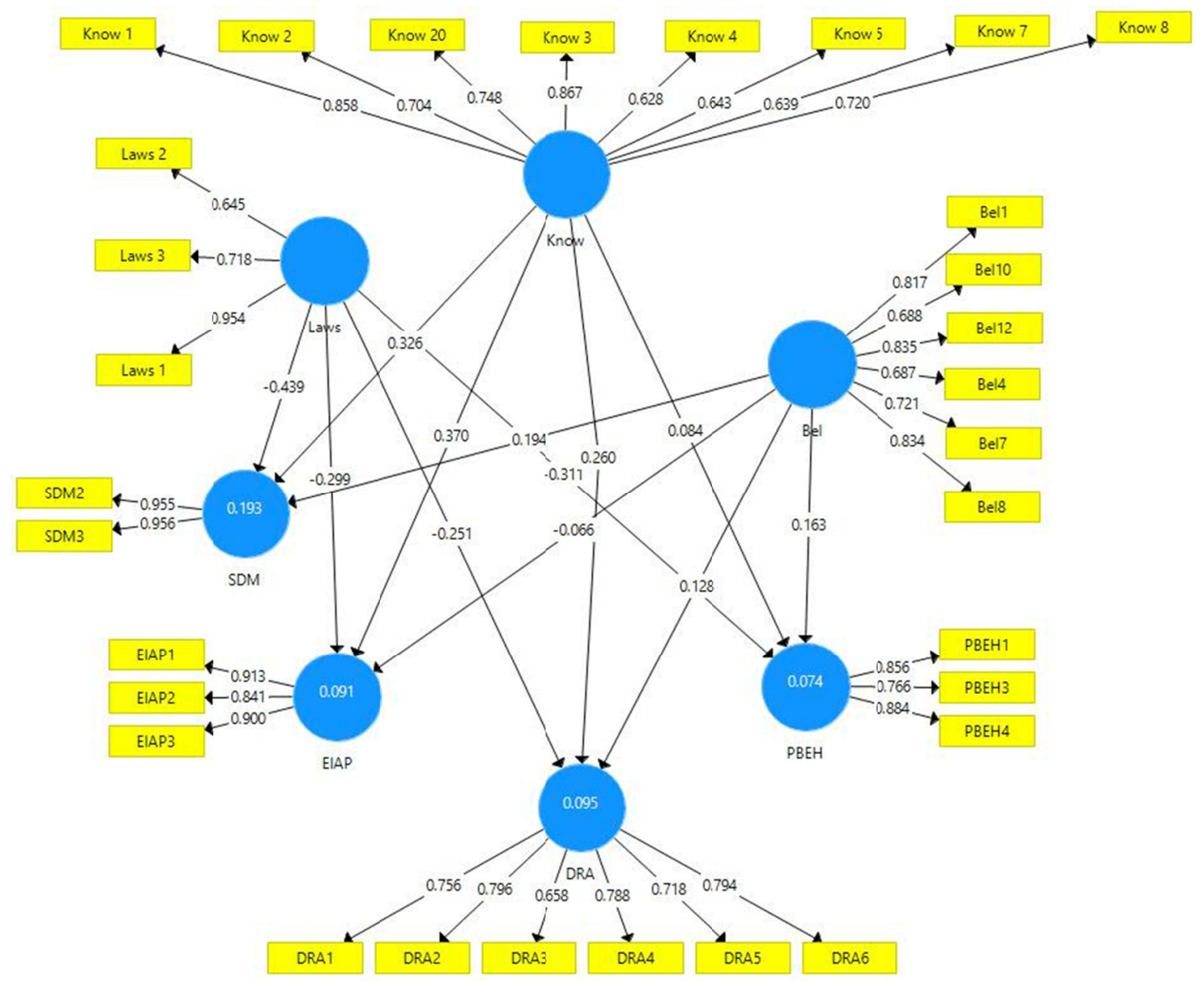

Figure 2. The structural model with estimated parameters

The third criterion which is used to assess structural model is the effect of size by $\mathrm{f}^{2}$. According to Cohen (1988), $\mathrm{f}^{2}$ values of $0.35,0.15$, and 0.3 and 0.02 signify large, medium, and small effects respectively. In our case, the effect size is significant only for the relationship between Laws and Speed. This result means that there is a stronger effect between Laws as exogenous variable and Speed as endogenous variable.

Table 10. Effect size f Square

\begin{tabular}{lccccc}
\hline & $\begin{array}{c}\text { Original } \\
\text { Sample }(\mathrm{O})\end{array}$ & $\begin{array}{c}\text { Sample Mean } \\
(\mathrm{M})\end{array}$ & $\begin{array}{c}\text { Standard } \\
\text { Deviation } \\
(\text { STDEV })\end{array}$ & $\begin{array}{c}\text { T Statistics } \\
(\mid \mathrm{O} / \text { STDEV } \mid)\end{array}$ & P Values \\
\hline Bel -> DRA & 0.00 & 0.01 & 0.02 & 0.34 & 0.72 \\
Bel -> EIAP & 0.00 & 0.00 & 0.01 & 0.17 & 0.86 \\
Bel -> PBEH & 0.01 & 0.01 & 0.02 & 0.61 & 0.53 \\
Bel -> SDM & 0.02 & 0.02 & 0.02 & 0.75 & 0.44 \\
Know -> DRA & 0.02 & 0.04 & 0.03 & 0.91 & 0.36 \\
Know -> EIAP & 0.05 & 0.05 & 0.04 & 1.45 & 0.14 \\
Know -> PBEH & 0.00 & 0.01 & 0.01 & 0.20 & 0.83 \\
Know -> SDM & 0.05 & 0.04 & 0.03 & 1.57 & 0.11 \\
Laws -> DRA & 0.04 & 0.05 & 0.03 & 1.33 & 0.18 \\
Laws -> EIAP & 0.06 & 0.06 & 0.04 & 1.61 & 0.10 \\
Laws -> PBEH & 0.07 & 0.08 & 0.05 & 1.33 & 0.18 \\
Laws -> SDM & 0.16 & 0.13 & 0.07 & 2.22 & $0.02 *$ \\
\hline
\end{tabular}

$* \mathrm{p}<.05$ 
According to the results of assessing reflective and affective constructs, the fit indices of the global model were acceptable. When compared against the thresholds, statistical index and coefficients show that SRMR for Common Factor Model and SRMR for Composite Model have a statistical significant p-value ( $<5 \%)$. Henseler, J., et al. (2014); Hu, Li-tze \& Bentlerb, P. M., (1999) defined SRMR as the difference between the observed correlation and the predicted correlation. Hence, this coefficient permits evaluating the average degree of the inconsistencies between observed and expected correlations as an absolute measure of (model) fit criterion. In our case, the value of SRMR is less than 0.10 and it is considered a good fit. The Table 11 shows that there are 5 effects between endogenous and exogenous constructs. The first direct effect is between (Bel -> SDM); the second direct effect is between (Know -> EIAP); the third direct effect is between (Know -> SDM); the fourth direct effect is between (Laws -> DRA) and the fifth direct effect is between (Laws -> SDM). The results presented no indirect effects for all endogenous and exogenous variables.

Table 11. Total effects

\begin{tabular}{lccccc}
\hline & $\begin{array}{c}\text { Original } \\
\text { Sample }(\mathrm{O})\end{array}$ & $\begin{array}{c}\text { Sample Mean } \\
(\mathrm{M})\end{array}$ & $\begin{array}{c}\text { Standard } \\
\text { Deviation } \\
(\text { STDEV })\end{array}$ & $\begin{array}{c}\text { T Statistics } \\
(\mid \mathrm{O} / \text { STDEV } \mid)\end{array}$ & P Values \\
\hline Bel -> DRA & 0.12 & 0.13 & 0.12 & 1.01 & 0.31 \\
Bel -> EIAP & -0.06 & -0.05 & 0.11 & 0.57 & 0.56 \\
Bel -> PBEH & 0.16 & 0.15 & 0.11 & 1.41 & 0.15 \\
Bel -> SDM & 0.19 & 0.19 & 0.09 & 1.98 & $0.04^{*}$ \\
Know -> DRA & 0.26 & 0.24 & 0.14 & 1.75 & 0.07 \\
Know -> EIAP & 0.37 & 0.31 & 0.13 & 2.67 & $0.00^{*}$ \\
Know -> PBEH & 0.08 & 0.05 & 0.13 & 0.60 & 0.54 \\
Know -> SDM & 0.32 & 0.27 & 0.11 & 2.80 & $0.00^{*}$ \\
Laws -> DRA & -0.25 & -0.22 & 0.12 & 1.97 & $0.04 *$ \\
Laws -> EIAP & -0.29 & -0.22 & 0.15 & 1.90 & 0.05 \\
Laws -> PBEH & -0.31 & -0.23 & 0.18 & 1.66 & 0.09 \\
Laws -> SDM & -0.43 & -0.34 & 0.16 & 2.62 & $0.00^{*}$ \\
\hline
\end{tabular}

$* \mathrm{p}<.05$

\section{Discussion of Research Findings}

The findings tend to validate and accept 5 of the 12 hypotheses established in the conceptual framework. Also, there was a positive direct influence between the speed of decision-making process and the knowledge of bank managers. The hypothesis H1a is shown as the path from (Know -> SDM) in figure 2. The standardised coefficient of this path was 0.326 , the $t$-value was 2.803 , which was significant at $\alpha=0.05$. The significant coefficient provided evidence of support for H1a. These results support the studies of Jarratt, D., Stiles, D., (2010); Vangelis, S., Marcello, M., (2010); Koskinen, J., et al., (2010); and Rajagopalan, N., et al., (1993) which proved the impact of knowledge as determinant of culture, and the speed of the decision-making process as determinant of SDMP. The hypothesis H1b is not supported and there was no relationship between knowledge of bank managers and the degree of rationality (Know -> DRA). The standardised coefficient of this path was 0.260 , the t-value was 1.757 , which was not significant at $\alpha=$ 0.05 ( $p$-value $=0.079>0.05$ ). The hypothesis H1c is rejected and there was no relationship between knowledge of bank managers and political behaviours (Know -> PBEH). The standardised coefficient of this path was 0.084, the t-value was 0.608 , which was not significant at $\alpha=0.05(\mathrm{p}$-value $=0.544>0.05)$. These results corroborate the findings of Parsons, T., \& Shils, E.A., (2001); Hills, M. D. (2002); Kluckhohn, F. R. \& Strodtbeck, F. L. (1961). Moreover, the hypothesis H1d is supported and there was a correlation between knowledge of banks managers and the elements of involvement and participation (shown as the path Know -> EIAP in Figure 2). But the sign of this relationship is positive and the standardised coefficient of this path was 0.370 , the t-value was 2.678 , which was significant at $\alpha=0.05$. The significant coefficient provided evidence of support for H1d. Also, the results confirm the contribution presented by John, P.L., (1995); Nonaka, I. \& Takeuchi, H., (1997); Raissi, N., (2015); and Wooldridge, B., \& Floyd, S.W., (1990) on the relationship between knowledge and participation in the decision making process. The hypothesis $\mathrm{H} 2 \mathrm{a}$ is presented as the path from (Bel -> SDM) in fig 2 . The speed of decision making is positively 
associated with the beliefs, attitudes and values of the top management team (decision makers). The standardised coefficient of this path was 0.194 , the $\mathrm{t}$-value was 1.984 , which was significant at $\alpha=0.05$. The significant coefficient provided evidence of support for H2a. The studies of Ahmad, M. S., (2012); Ishak, M.S., et al., (2013); and Judge, W.Q., \& Miller, A., (1991) confirm our findings that beliefs and values, which are widely accepted as some of the strongest organisational cultural factors are related to the SDM, which are a valuable source of a firm's competitive advantage. Furthermore, the hypotheses H2b, H2c and H2d were rejected, and there was no relationship between beliefs, attitudes and values of the top management team as exogenous variable and the degree of rationality (DRA), the elements of involvement and participation (EIAP), and political behaviours (PBEH) as endogenous variables. The standardised coefficient of the path from (Bel -> DRA) was 0.128, the t-value was 1.010, which was not significant at $\alpha=0.05$ ( $\mathrm{p}$-value $=0.313>0.05$ ). In the same way, the standardised coefficient of the path from (Bel -> EIAP) was - 0.066, the t-value was 0.572 , which was not significant at $\alpha=0.05$ ( $\mathrm{p}$-value $=0.567>0.05$ ). The final relationship not approved was between (Bel -> PBEH) and the standardised coefficient of this path was 0.163, the $\mathrm{t}$-value was 1.410 , which was not significant at $\alpha=0.05$ ( $\mathrm{p}$-value $=0.159>0.05$ ). The authors Aycan, Z., et al., (1999) confirmed our results that the organisation's internal environment has a special standard, and that there is no significant relationship between beliefs, degree of rationality, political behaviours and participation. The impact of Laws as determinant of culture on strategic decision making process (SDMP) is tested within hypothesis 3. The hypothesis $\mathrm{H} 3 \mathrm{a}$ is presented as the path from (Laws -> SDM) in fig 2. The speed of decision making will positively affect Laws. The standardised coefficient of this path was -0.439 , the $t$-value was 2.621 , which was significant at $\alpha=$ 0.05. The significant coefficient provided evidence of support for H3a. However, in this case, the sign of standardised coefficient is negative. Thus, the relationship between Laws and SDM is negative. The correlation between Laws and degree of rationality is tested by the hypothesis H3b. The hypothesis H3b is presented as the path from (Laws -> DRA) in fig 2. Laws will positively affect the degree of rationality. The standardised coefficient of this path was -0.251 , the $t$-value was 1.979 , which was significant at $\alpha=0.05$. The significant coefficient provided evidence of support for $\mathrm{H} 3 \mathrm{~b}$. In this case, the sign of standardised coefficient is negative. Thus, the relationship between Laws and DRA is negative. These results were confirmed by Abu-Qaued, F. M., et al. (2014); Mautner, M., (2011); and Miller, C.C., \& Ireland, R.D., (2005) which proved that a major feature of organisational culture is the connection between law and culture. After testing the Hypotheses $\mathrm{H} 3 \mathrm{c}$ and $\mathrm{H} 3 \mathrm{~d}$, the results provide no correlation between Laws and the elements of involvement and participation (EIAP), and political behaviours (PBEH). The standardised coefficient of the path from (Laws -> EIAP) was -0.299 , the t-value was 1.901, which was not significant at $\alpha=0.05$ (p-value $=0.058>0.05$ ). Moreover, the standardised coefficient of the path from (Laws -> PBEH) was -0.311 , the $t$-value was 1.667 , which was not significant at $\alpha=0.05$ (p-value $=0.096>0.05$ ). The authors Westbrook, J.K., (1993); Anderson, E.A. \& Adams D., (1997); Robert A. \& Andrew S., (2007); and Mintzberg, H., (1990) confirmed that innovation, communication, and effectiveness in the workplace can be able to control the processes that are efficient and in line with the culture and vision of organisations.

\section{Conclusions, Limitations and Further Research}

The objective of this study was to create a model that will include the culture represented by beliefs, laws and knowledge; and clarify their impact on strategic decision-making process. The research comprised two main elements. The first was to examine the relationship between banking system practices using organisational culture, and mangers' decision-making. The second was to determine how these organisational culture factors influence strategic decision-making processes (SDMP). This study will develop an integrative model that explains the link between banks' culture and managers' strategic decision-making processes. Also, the key Research Questions considered were:

\section{What cultural factors are critical to the SDM process of banks?}

2. How do these cultural factors affect bank managers in making strategic decisions?

As a result, it is essential to take into account the cultural differences within countries. Bank managers must do so to understand both their international partners and relevant competitors that need to be overtaken to increase their leverage. Managers must also be capable of running their banks in the most effective manner possible (Dabic, M., et al., 2015). Moreover, the differences in banks decision-making styles are crucial, because there is a concrete link between cognitive diversity, cultural diversity and the outcomes of strategic decisions (Olson, B., et al., 2007). There are significant differences in the thinking, strategies, and experience of the Islamic managers and conventional bank management. Decision-making is not only based on the structural pressures facing the managers and the organisational processes that impact day-to-day banking operations, it is also based on a myriad of individual belief systems, socialisation setups, cultural and ethical norms (Guo, P., \& Li, Y., 2011). According to Hofstede, G., (1991, 2001) culture generally sums up the knowledge, beliefs, art, laws, moral norms or customs that serve to differentiate one group from the other; cited by Bogdan, I., Frăticiu, L., (2014); and Obeidat, B., et al., (2012). Although cultural values are preserved in different models while studying cultural diversity, they are less effective in studying the 
nature of the strategic decision making (SDM) model. Moreover, as Cheng, V., et al., (2010) observed in previous strategic decision making studies, the majority of cultural factors that influence organisational management decisions can be grouped into four main categories, including, locus of control, group orientation, hierarchy, and the decision mode and style. Locus of control and decision mode and style essentially relates to decision makers' cognitive attributes. While on the other hand, hierarchy and group orientation concerns the horizontal and vertical social relationships which affect decision makers inside a decision team, such as Saudi Arabian banks (Singh, A., et al., 2006). Similarly, Rajagopalan, N., et al.,(1993) examined the previous SDM studies and noted four main features of the Strategic Decision-Making Process, including, speed of decision-making, the degree of rationality, political behaviours, and the elements of involvement and participation. In this research, the four SDMP factors were adopted to measure the link between strategic decision-making process and culture determinants (beliefs, knowledge and laws). This study identified the considerable influence of culture on SDMP. The findings of structural equation modelling (SEM) analysis indicate that the determinants of culture (beliefs, knowledge and laws) are significantly associated with each dimension of SDMP. Furthermore, the results show that the knowledge of bank managers is positively associated with the speed of the SDM process and participation. Likewise, the speed of decision making is positively associated with the beliefs, attitudes and values of the top management team (decision makers). Finally, Laws are positively associated with the speed of decision making and the degree of rationality. The results of this research demonstrate support for 5 of the 12 hypotheses. It also indicates that, managers' decisions are largely based on the culture of their relevant organisations. The process of decision-making will have a better quality if knowledge, beliefs and laws are taken into account and if they are achieved through these 3 culture determinants. Thus, bank managers should include culture as a leverage to ensure the efficiency of SDMP (Dabic, M., et al., 2015). The diversity of factors that affect strategic decision-making process as a research topic presented a number of limitations; the study is limited to Hofstede's model on organisational culture, and in reality, many factors can be tested and compared to define a strong model which includes more than the culture dimension (knowledge, beliefs and laws). It will be helpful in further studies to research the degree of acceptance of leadership style, the employee-oriented vs. work-oriented, open system vs. closed system (organisational environment), local vs. professional, easy-going work discipline vs. strict work discipline, internally driven vs. externally driven, means-oriented vs. goal-oriented, and the degree of identification with organisation. Moreover, the researchers can include the performance as endogenous variable, the SDMP as a mediator variable and the culture determinants as exogenous variable in the model may give other results and contributions in this research topic.

\section{References}

Abdul Rasid, S.Z., AbdullManaf, M., \& Quoquab, F. (2013). Leadership and Organizational Commitment in the Islamic Banking Context: The Role of Organizational Culture as a Mediator. American Journal of Economics, 3(5C), 171-176. http://dx.doi.org/10.5923/c.economics.201301.29

Abu-Qaued, F.M., Khraim, H.S., \& Al-Kwere, O.A. (2014). Strategic Marketing: The Case of Islamic Bank of Jordan. European Journal of Business and Innovation Research, 2(5), 55-70.

Ahmad, M.S. (2012). Impact of Organizational Culture on Performance Management Practices in Pakistan. Business Intelligence Journal, 5(1), 50-55.

Ahmed, M., \& Shafiq, S. (2014). The Impact of Organizational Culture on Organizational Performance: A Case Study of the Telecom Sector. Global Journal of Management and Business Research, 14(3), 21-30.

Albdour, A.A., \& Altarawneh, I.I. (2014). Employee Engagement and Organizational Commitment: Evidence from Jordan. International Journal of Business, 19(2), 192-212.

Albert, W.J. (1988). Free trade and cultural industries. In Marc Gold et David Leyton-Brown (dir.), Trade-Offs on Free Trade - The Canada-U.S. Free Trade Agreement (p. 350). Toronto, Carswell.

Andersen, T.J. (2004). Integrating Decentralized Strategy Making and Strategic Planning Processes in Dynamic Environments. Journal of Management Studies, 41, 1271-1299.

Anderson, E.A., \& Adams, D. (1997). Evaluating the success of TQM implementation: Lessons from employees. Production and Inventory Management Journal, 38(4), 1-6.

Anderson, J.C., \& Gerbing, D.W. (1988). Structural Equation Modeling in Practice: A Review and Recommended Two-step Approach. Psychological Bulletin, 103(3), 411-423.

Andrew, B. (1995). Organisational Culture (1st ed.). Pitman Publishing.

Andrew, B. (1998). Organisational Culture (2nd ed.). Financial Times Management Publishing.

Aycan, Z., Kanungo, R.N., \& Sinha, J.B.P. (1999). Organizational culture and human resource management practices: The model of culture fit. Journal of Cross-Cultural Psychology, 30(4), 501-526. 
Bogdan, I., \& Frăticiu, L. (2014). Managementul grupurilor de muncă: subsistem de management, important, specific acestui secol. Editura Universităţii Lucian Blaga, Sibiu.

Cassel, C.M., Hackl, P., \& Westlund, A.H. (2000). On measurement of intangible assets: A study of robustness of partial least squares. Total Quality Management, 11(7), 897-907.

Cheng, V., Rhodes, Jo., \& Lok, P. (2010). A framework for strategic decision making and performance among Chinese managers. The International Journal of Human Resource Management, 21(9), 1373-1395.

Chin, W.W. (1998). The partial least squares approach to structural equation modelling. In G. A. Marcoulides (Ed.), Modern Methods for Business Research (pp. 295-358). Mahwah, NJ: Lawrence Erlbaum Associates.

Cronbach, L.J. (1951). Coefficient alpha and the internal structure of tests. Psychometrika, 16(3), $297-334$.

Dabic, M., Tipuric, D., \& Podrug, N. (2015). Cultural differences affecting decision-making style: a comparative study between four countries. Journal of Business Economics and Management, 16(2), 275-289.

Davison, A.C., \& Hinkley, D.V. (2003). Bootstrap methods and their application (2nd ed.). New York, NY: Cambridge University Press.

Dess, G.G., \& Lumpkin, G.T., \& Eisner, A.B. (2007). Strategic management: creating competitive advantage. New York: McGraw - Hill / Irwin.

Diamantopoulos, A., \& Winklhofer, H. (2001). Index construction with formative indicators: An alternative to scale development. Journal of Marketing Research, 38(2), 269-277.

Ehtesham, M., \& Muhammad, T.M., \& Muhammad, S.A. (2011). Relationship between Organizational Culture and Performance Management Practices: A Case of University in Pakistan. Journal of Competitiveness, 1(4), 78-86.

Eisenhardt, K., \& Bourgeois, L.J. (1988). Politics of strategic decision making in high-velocity environments: Toward a midrange theory. Academy of Management Journal, 31, 737- 770.

Eisenhardt, K., \& Bourgeois, L.J. (1989). Charting strategic decisions: Profile of an industry star. In M. Van Glinow \& S. Mohrmann (Eds.), Managing complexity in high technology organizations, systems, and people: Forthcoming. New York: Oxford University Press.

Eisenhardt, K.M., \& Zbaracki. M.J. (1992). Strategic decision making. Strategic Management Journal, 13(S2), 17-37.

Eliot, T.S. (1888). The Modernist in History. (Ed. Ronald Bush), California Institute of Technology.

Evrard, Y., Bernard, P., \& Elyette, R. (2009). Market: Fondements et méthodes des recherches en marketing (4ième édition). Les Editions Dunod, Paris.

Fornell, C., \& Larcker, D.F. (1981). Structural equation models with unobservable variables and measurement error: Algebra and statistics. Journal of Marketing Research, 18(3), 328-388.

Fredrickson, J.W., \& Mitchell, T.R. (1984). Strategic Decision Processes: Comprehensiveness and Performance in an Industry with an Unstable Environment. Academy of Management Journal, 27, 399-423.

Frishammar, J. (2003). Information use in strategic decision making. Management Decision, 41(4), 318-326.

Götz, O., Liehr-Gobbers, K., \& Krafft, M. (2009). Evaluation of structural equation models using the partial least squares (PLS) approach. In V. Esposito Vinzi, W. W. Chin, J. Henseler \& H. Wang (Eds), Handbook of partial least squares: Concepts, methods, and applications. Berlin: Springer (in print).

Grewal, R., Cote, J.A., \& Baumgartner, H. (2004). Multicollinearity and measurement error in structural equation models: Implications for theory testing. Marketing Science, 23(4), 519-529.

Guo, P., \& Li, Y. (2011). Multistage decision making based on one-shot decision theory. In Advances in Intelligent and Soft Computing, Knowledge Engineering and Management (Part III). Publisher: Springer Berlin Heidelberg, 123, 159-164. http://dx.doi.org/10.1007/978-3-642-25661-5_21

Hall, E.T. (1976). Beyond Culture. Garden City, NY; Anchor Books.

Henseler, J., Dijkstra, T.K., Sarstedt, M., Ringle, C.M., Diamantopoulos, A., Straub, D.W., ... Calantone, R.J. (2014). Common beliefs and reality about partial least squares: comments on Rönkkö \& Evermann (2013), Organizational Research Methods, 17(2), 182-209.

Henseler, J., Hubona, G., \& Ash Ray, P. (2016, Using PLS path modeling in new technology research: updated guidelines. Industrial Management \& $\quad$ Data $\quad$ Systems, $116(1), \quad 2-20$. http://dx.doi.org/10.1108/IMDS-09-2015-0382 
Heracleous, L., \& Langham, B. (1996). Strategic change and organizational culture at Haymanagement consultants. Long Range Planning, 29(4), 485-494.

Hills, M.D. (2002). Kluckhohn and Strodtbeck's Values Orientation theory. Online Readings in Psychology and Culture, 4(4). http://dx.doi.org/10.9707/2307-0919.1040.

Hitt, M.E., Hoskisson, R.E., \& Ireland, R.D. (2006. Management of strategy: concepts and cases. Mason: Thomson South-Western.

Hofstede, G. (1980). Culture's consequences: International differences in work-related values. Beverly Hills; London: Sage Publications.

Hofstede, G. (1991). Cultures and Organizations: Software of the Mind. London: McGraw-Hill

Hofstede, G. (2001). Culture's Consequences. Second Edition: Comparing Values, Behaviors, Institutions and Organizations across Nations. London: Sage.

Hu, Li-tze, \& Bentlerb, P.M. (1999). Cutoff criteria for fit indexes in covariance structure analysis: Conventional criteria versus new alternatives. Structural Equation Modeling: A Multidisciplinary Journal, 6(1), 1-55. http://dx.doi.org/10.1080/10705519909540118

Ishak, M.S., Ahmad, M., Rahman, M.N. A., \& Rofie, M.K. (2013). Predicting intentions to visit kopitiams as halal food outlet: An extension of the Theory of Planned Behavior. In 4th International Conference on Business and Economic Research (4th ICBER 2013) Proceeding (pp. 850-861).

Jarratt, D., \& Stiles, D. (2010). How are methodologies and tools framing managers' strategizing practice in competitive strategy development? British Journal of Management, 21(1), 28-43.

John, P.L. (1995). Preparing for Peace - Conflict transformation across cultures. Syracuse, Syracuse University Press.

Judge, W.Q., \& Miller, A. 1991). Antecedents and Outcomes of Decision Speed in Different Environment Contexts. Academy of Management Journal, 34(2), 449-463.

Kilmann, R., Saxton, M.J., \& Serpa, R. (1985). Introduction: five key issues in understanding and changing culture. In Kilmann, R., Saxton, M.J. and Serpa, R. and associates (Eds.), Gaining Control of Corporate Culture. Jossey-Bass Pulishers, San Fransico, CA.

Kluckhohn, F.R., \& Strodtbeck, F.L. (1961). Variations in value orientations. Evanston, IL: Row, Peterson.

Koskinen, J., \& Kagoné, M., Souares, A., \& Sauerborn, R. (2010). The Influence of Organizational Culture on Information Use in Decision Making within Government Health Services in Rural Burkina Faso. Nordic Journal of African Studies, 19(4), 250-273.

Laurent, A. (1983). The Cultural Diversity of Western Conceptions of Management. International Studies of Management and Organization, XIII(1/2), 75-96.

Laurent, A. (1986). The Cross-Cultural Puzzle of International, Human Resource Management. Human Resource Management, 25(1), 91-102.

Lund, D.B. (2003). Organizational culture and job satisfaction. Journal of Business \& Industrial Marketing, 18(3), 219-236.

Mautner, M. (2011). Three Approaches to Law and Culture. Cornell Law Review, 96, 839. Retrieved from http://ssrn.com/abstract $=1862606$

McClelland, D.C. (1961). The achieving society. Princeton, NJ: Van Nostrand.

Mehta, S., \& Krishnan V.R. (2004). Impact of Organizational Culture and Influence Tactics on Transformational Leadership. Journal of Management and Labor Studies, 29(4), 281-290.

Miller, C.C., \& Ireland, R.D. (2005). Intuition in SDM: Friend or Foe in the Fast-paced 21st Century? Academy of Management Executive, 19(1), 19-30.

Miller, D., Burke, L., \& Glick, W. (1998). Cognitive Diversity among Upper-echelon Executives, Strategic Management Journal, 19, 39-58.

Mintzberg, H. (1990). Strategy Formation: Schools of Thought. In Fredrickson J. W (Ed.), Perspectives on Strategic Management (105-236). New York: Harper Business.

Nonaka, I., \& Takeuchi, H. (1995). The knowledge-creating company. New York, Oxford: Oxford University Press.

Obeidat, B., Shannak, R., Masa'deh, R., Al-Jarrah, I. (2012). Toward better understanding for Arabian culture: 
Implications based on Hofstede's cultural model. European Journal of Social Sciences, 28(4), 512-522.

Olson, B., Bao, Y., \& Parayitam, S. (2007). Strategic decision-making within Chinese firms. JWB, 42, 35-46.

Online Cambridge English Dictionary. Retrieved 2016, from http://ictionary.cambridge.org/

Ovidiu-Iliuta, D. (2014). The Link between Organizational Culture and Performance Management Practices: A Case of Companies from Romania. Annals of the University of Oradea, Economic Science Series, 23(1), 1156-1163.

Parsons, T., \& Shils, E.A., (Eds). (2001). Toward a General Theory of Action: Theoretical Foundations for the Social Sciences. New Brunswick, NJ: Transaction Publishers. Originally published 1951.

Pettigrew, A. (1973). The Politics of Organizational Decision Making. London: Tavistock.

Powell, T.C. (1992). Organizational Alignment as Competitive Advantage. Strategic Management Journal, 13(2), $119-134$.

Raissi, N. (2015). Pre-Certification Requirements of Integrated Management System and its Consequences on Human Resource Behavior: An Empirical Investigation of Tunisian Industry. European Journal of Economics, Finance and Administrative Sciences, 9(74), 52-84.

Rajagopalan, N., Rasheed, A.M.A., \& Datta, D.K. (1993). Strategic Decision Processes: Critical Review and Future Directions. Journal of Management, 19(2), 349-384.

Robert, A., \& Andrew, S. (2007). Let Chaos Reign, Then Rein In Chaos-Repeatedly: Managing Strategic Dynamics For Corporate Longevity. Strategic Management Journal, 28(1), 965-979.

Said, E. (2006). Strategic decision-making: Process perspectives. International Journal of Management Reviews, 8 , 1-20. http://dx.doi.org/10.1111/j.14682370.2006.00118.x.

Salem, Z.O., \& Agil, S.O.S. (2012). The Effects of Islamic Management Ethics on Organizational Commitment of Employees in Libyan Public Banks. Australian Journal of Basic and Applied Sciences, 6(7), 260-270.

Schein, E.H. (1985). Organizational Culture and Leadership. University of Illinois at Urbana-Champaign's Academy for Entrepreneurial Leadership Historical Research Reference in Entrepreneurship. Retrieved15 April 2016, fromhttp://ssrn.com/abstract $=1496184$

Schein, E.H. (1990). Organizational culture. American Psychologist, 43(2), 109-119.

Schein, E.H. (1992). Organizational Culture and Leadership (2d ed.). San Francisco, CA.: Jossey-Bass.

Schein, E.H. (1995). Organizational culture. Campus Verlag, Frankfurt/New York.

Schein, E.H. (2004). Organizational culture and leadership (3rd. ed.). Jossy-Bass.

Singh, A., Narain, R., \& Yadav, R.C. (2014). Benchmarking and performance measurement of supply chain management practices: a survey of Indian organisations, International Journal of Services and Operations Management (IJSOM), 2(4), 313-334.

Sun, S. (2008). Organizational culture and its themes. International Journal of Business and Management, 3(12), 137-300.

Tenenhaus, M., Esposito Vinzi, V., Chatelin, Y.-M., \& Lauro, C. (2005). PLS path modeling. Computational Statistics \& Data Analysis, 48(1), 159-205.

Trompenaars, F. (1994), L'entreprise multiculturelle, Maxima.

Tylor, E. (1889). On a Method of Investigating the Development of Institutions; Applied to Laws of Marriage and Descent. The Journal of the Anthropological Institute of Great Britain and Ireland, 18(3), 245-272.

Vangelis, S., \& Marcello, M. (2010). Polychronicity in Top Management Teams: The Impact on Strategic Decision Processes and Performance of New Technology Ventures. Strategic Management Journal, 31(1), 652-678.

Vilares, M.J., Almeida, M.H., \& Coelho, P.S. (2009). Comparison of likelihood and PLS estimators for structural equation modeling: A simulation with customer satisfaction data. In Esposito, V., \& Chin, W.W., \& Henseler, J., \& Wang, H., (Eds), Handbook of partial least squares: Concepts, methods, and applications. Berlin: Springer (inprint).

Westbrook, J.K. (1993). Organizational culture and its relationship to TQM. Industrial Management. 35(1), 1-3.

Williams, L.J., Edwards, J.R., \& Vandenberg, R.J. (2003). Recent Advances in Causal Modeling Methods for Organizational and Management Research. Journal of Management, 29(6), 903-936.

Wooldridge, B., \& Floyd, S.W. (1990). The Strategy Process, Middle Management Involvement, and Organizational Performance, Strategic Management Journal, 11, 231-241. 